\title{
EL AMOR Y EL DERECHO EN CERVANTES
}

\author{
LOVE AND THE LAW IN CERVANTES
}

\section{ROBERTO GONZÁLEZ ECHEVARRÍA ${ }^{1}$}

\section{RESUMEN}

La convergencia de la historia del derecho y el surgimiento del realismo novelístico en occidente hasta la España de los Reyes Católicos, cuando la creación de un estado moderno produce un sistema judicial centralizado, de donde surge la figura del pícaro y la descripción de la vida cuotidiana en la ficción, especialmente la de los criminales. Cervantes incorpora estas novedades en su Quijote, en el que personajes como Ginés de Pasamonte, autor picaresco y galeote aparecen. Se analiza una figura menor, otro de los galeotes de la primera parte, capítulo 22, que ha sostenido relaciones sexuales con cuatro mujeres, dos de ellas primas suyas, con las cuales tuvo varios hijos, de lo cual hace alarde en un parlamento que revela que es un estudiante de derecho, subrayándose así el vínculo entre la novela y el derecho.

Palabras clave: Derecho, historia del derecho, picaresca, realismo, desarrollo de la novela, Cervantes, Quijote.

\section{ABSTRACT}

The convergence of the history of the law and the emergence of novelistic realism in the West, especially in the Spain of the Catholic Kings where the creation of a new modern state gave rise to an increasingly centralized judicial system, is where the figure of the picaro emerges and the depiction of everyday life in fiction, particularly that of criminals. Cervantes incorporates these developments into his Quijote, in which characters like Ginés de Pasamonte, a picaresque author and galley slave, appear. A minor figure, one of the galley slaves in Part One Chapter 22, is analyzed. He has had sexual relations

${ }^{1}$ Doctor en Lenguas Romances. Sterling Professor of Comparative Literature, Yale University. Connecticut, EE.UU.E-mail: r.gonzalezechevarria@yale.edu

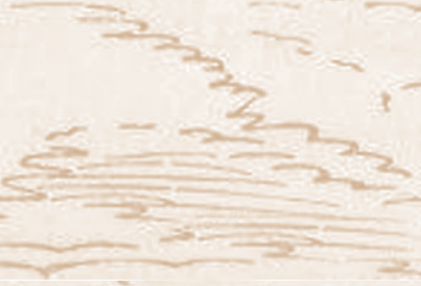

trat 
simultaneously with four women, two of them his cousins and with whom he has had multiple children. He boasts about these relationships in a speech that reveals that he is a law student, thus highlighting the link between the novel and the law.

Keywords: Law, history of law, picaresque, realism, development of the novel, Cervantes, Quijote.

Recibido: 21.11.11. Aceptado: 05.01.12.

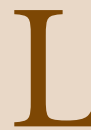

A NOVELA COMO GÉNERO literario y la de Cervantes en particular no se originan únicamente de la tradición literaria sino también de otros tipos de discurso, sobre todo el legal. Mi tesis sobre los orígenes del realismo es distinta de la que proponen Erich Auerbach (1950) en su clásico Mimesis, y más específicamente de la del realismo español propuesta por Alexander A. Parker (1967) en su Literature and the Delinquent: The Picaresque Novel in Spain and Europe. Auerbach destaca la evolución de los estilos, Parker el desarrollo de la Picaresca a partir de la literatura didáctico-moral durante la segunda mitad del siglo XVI. Yo propongo que la organización de un estado moderno en España, proceso que empieza durante el reinado de los Reyes Católicos, y el crecimiento de una burocracia patrimonial, generó un discurso idóneo para lidiar con criminales y la gente común que a los escritores les resultó seductor en parte porque les atañía a ellos mismos también como súbditos, ya que la condición y clase social de éstos había decaído; ya no provenían del clero o de la aristocracia. Propongo, además, que en la ficción el derecho incide sobre todo en conflictos de índole amorosa, sinécdoque de los conflictos sociales en general: el amor y el derecho se dan cita en el matrimonio, la institución religiosa y jurídica en la base misma del Estado. El derecho le suministra a Cervantes nuevas formas narrativas para renovar relatos tradicionales y escribir otros nuevos sacados de la vida contemporánea.

La relevancia del derecho español desde la Edad Media la demuestran las acciones del Cid Campeador tras la "Afrenta de Corpes," cuando los Infantes de Carrión maltratan a sus hijas: acude a Alfonso VI para que éste, no él mismo, haga justicia. Aunque los castellanos habían heredado la poesía heroica de los visigodos, sus códigos habían sido "romanizados," de manera que se prohibía la venganza privada. Todo el Poema de mío Cid gira en torno a un conflicto legal y su resolución en las Cortes de Toledo. La relación del individuo con el Estado a través del derecho y el aparato judicial ya está presente aquí -se desarrollará luego en La Celestina, la picaresca y las obras de Mateo Alemán y Cervantes. 
Jacob Grimm (1991 [1882]) propuso la consustancialidad del derecho y la poesía en sus orígenes, y Colin Smith (1983) declara, refiriéndose a la España medieval, que "los abogados escribían habitualmente en un lenguaje rico en ritmos, aliteraciones, y otras figuras". Otros proponen la consustancialidad de derecho y gramática, proponiendo que las leyes profundas del idioma son las primitivas en la base de todo discurso. Yo me inclino, con Grimm, por la poesía, porque me parece que la mera gramática no puede contener la voluntad creadora. En el occidente judeocristiano, tal vez en cualquier parte, la ley surge con el primer "no": no comer del árbol de la ciencia. La ley se origina en la prohibición y la necesidad de orden, algo que controle el caos del deseo sin límites. El "no" fundacional surge simultáneamente con el "sí" que se le opone -el "sí" de Molly Bloom al final del Ulises de Joyce. El deseo es el movimiento, el impulso al que la ley da forma, por eso es que las historias de amor usualmente aparecen en los principios de todas las mitologías y teogonías, e incluyen la violencia, como en la Afrenta de Corpes. La lengua poética se aloja en ese par compuesto del "sí" y el "no," deseo y ley: la rima, la aliteración, las figuras son la música de esa danza de contrarios, haciendo con ellas posible su legibilidad. La culpa y el ansia de perdón están profundamente incrustadas en ese drama primitivo, expresados en nuestra cultura por el concepto del pecado original -no puede haber deseo sin prohibición, y por lo tanto no hay acto o acción sin posible transgresión. Todas las demás infracciones repiten ésta original, transformada en religión y literatura. El psicoanálisis es la versión pálida, moderna de todo esto, porque ha dejado atrás la poesía de su fuente originaria.

La recurrente convergencia de ley y literatura a lo largo de la historia resulta de estos orígenes comunes -tal vez de esa unidad original. Es así porque la pareja deseo-ley no debe verse como una oposición binaria en que la ley representa lo racional y el amor lo irracional. El origen de la ley, del no -miedo, voluntad de poder, agresión, culpa- puede ser tan irracional como el deseo mismo. Al "no" siempre se le puede responder “ipor qué no?”, que es lo que la literatura se atreve preguntar, como en el caso del "prisionero del sexo," personaje menor del Quijote que veremos más adelante. La noción de que la ley proviene de Dios cubre con un velo religioso el impulso irracional detrás de toda prohibición.

La historia formal de la relación entre ley y literatura empieza en el siglo XIII, en Bolonia, con la renovación y romanización del estudio del derecho y la fundación de las universidades. El derecho era un estudio humanístico que incluía muy principalmente la retórica. El tono humanístico se debe, amén del profundo vínculo lingüístico y poético visto, a que en ambos el derecho y la literatura se lidia con cuestiones fundamentales de la condi-

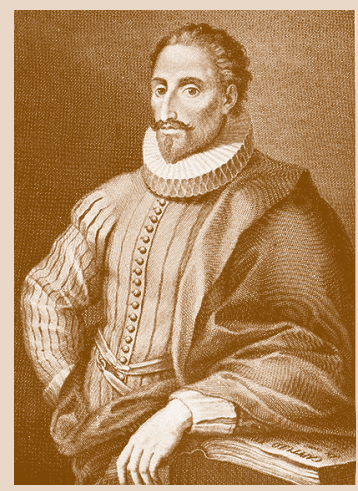

M. de Cervantes 


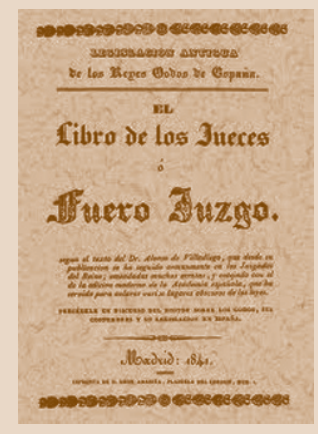

SIHTE PARTIDAS

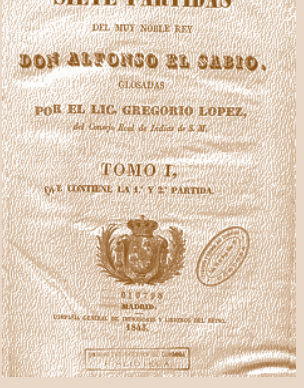

ción humana: el destino, la libertad, el bien y el mal, la verdad y la mentira, y cuestiones más mundanales como la indemnización, la venganza, el perdón, el matrimonio, las deudas públicas y privadas, la legitimidad, la lealtad y la traición. Tanto en el derecho como en la literatura estas cuestiones aparecen inicialmente como relatos fraguados en un lenguaje figurativo, cuya coherencia y validez tiene que ser evaluada para decidir sobre su veracidad: quién le hizo qué a quién, dónde, bajo qué circunstancias y haciéndose merecedor de qué recompensa o castigo. A partir de Bolonia estas historias se inscriben siguiendo las artes notariales. Los relatos jurídicos tienen argumentos que son una especie de gramática narrativa propia: secuencias de incidentes que incluyen el crimen y el castigo, conflictos y resoluciones en escenas de corte, y personajes tipos -criminales y víctimas, jueces y abogados, policías y verdugos. La ley captura en sus redes a los personajes más interesantes porque pretenden escapar de ella: los delincuentes son más atractivos que los ciudadanos comunes que respetan la ley, como es sabido.

La historia del derecho español pertinente a mis teorías empieza en la época del Poema de mío Cid ya mencionado y las Siete partidas-siglos XII y XIII. Es una legislación de origen visigótico, pero romanizada. Es también la época del Fuero juzgo, la recompilación más importante en occidente desde la de Justiniano. Todos esos códigos se basan -los sostiene- el concepto de la ley natural: la noción de que hay leyes inmutables derivadas de la razón que Dios dio a todo ser humano y que estaban encarnadas en la figura del Rey. Esas leyes eran principios indisputables, comprensibles para todos, y contra los cuales no había recurso -todo lo que estuviera en su contra era por definición ilegal. La ley natural es la fundación de las Siete partidas, el primer ejemplo de un monumento literario en lengua vernácula y en prosa que refleja la realidad presente, en contraste con la épica, que reflejaba un pasado heroico en verso. Las Siete partidas son un antecedente de la novela porque capturan en su prosa romance las minucias de la vida cotidiana. Una de las ideas presentes en las Siete partidas y El libro de buen amor, otra obra pertinente y coetánea, es que las leyes suponen la escritura, y que los reyes formulan leyes escritas que se recogen en libros. La producción y proliferación de tales libros en España aumenta durante el reinado de los Reyes Católicos.

La creación de un Estado moderno bajo Fernando e Isabel se lleva a cabo mediante la organización de lo que Max Weber llamó una burocracia patrimonial. Es decir un sistema de gobierno que sigue sus propias reglas internas, basadas, se supone, en la razón, la eficiencia y sincronización de todas las esferas, y cuyo personal se selecciona en base a su competencia, 
no al estatus social, pero cuya autoridad suprema estaba investida en el rey -por ello patrimonial. Esta organización alcanzó su cenit bajo Felipe II. El Santo Oficio de la Inquisición y la Santa Hermandad son ejemplos de organismos creados para fomentar la unificación ideológica y penal de la Península bajo los Reyes Católicos.

Del archivo penal creado por esta burocracia, que tendrá su sede en Simancas, emergen nuevos relatos y personajes literarios, especialmente el pícaro. La escritura legal nombra, señala, identifica al criminal según sus características morales y (sobre todo) físicas. La tradición literaria, por su aura de ser algo del pasado, carece de especificidad en sus detalles, no refleja las asperezas y deformidades del presente. Los nuevos personajes sacados o dibujados a imitación de los del archivo exhibirán de ahora en adelante rasgos definitorios, frecuentemente deformidades físicas debidas a accidentes o factores naturales, o a la violencia imperante en su mundo. En el Quijote, Ginés de Pasamonte es bizco, Juan Palomeque, el ventero, es zurdo (su sobrenombre es El Zurdo), Maritornes es fea en todo pormenor, Sancho tiene panza, Altisidora mal aliento, Aldonza apesta, y la Duquesa tiene lesiones supurantes en las piernas. Algunas de estos atributos son como los que tendrían los delincuentes cuyas fechorías se registran en documentos legales contenidos en el archivo, no marcas como la cicatriz de Ulises sobre la cual escribe Auerbach (1950). Por contraste con la oculta cicatriz del héroe homérico, los defectos físicos en la nueva literatura tienden a ser obvios e identificadores. Les confieren a los personajes una particularidad que los identifica y frecuentemente les merece sobrenombres, como en el caso de Palomeque. A Ginés le irrita que uno de los guardias traiga a colación su sobrenombre (Parapilla). Quintiliano Saldaña (1926) escribe que la mayoría de los criminales en época de Cervantes tenían sobrenombres que figuraban en sus antecedentes penales para su mejor identificación: Juan Pérez "El Tuerto", Damiana Sosa "La Caballona Machona", Antonio "El Borgoñón," y así sucesivamente. El discurso legal detalla e individualiza a los delincuentes, conservaba el expediente de sus naturales o accidentales rasgos físicos, y nombres de guerra -era un mecanismo de identificación que facilitaba su captura, como cuando el cuadrillero de la Santa Hermandad lee con dificultad la descripción de don Quijote contenida en la orden de arresto del hidalgo, deteniéndose después de cada palabra para mirar la cara del sujeto y comprobar que su fisonomía coincide con lo que el documento dice.

Entre los crímenes cometidos por todos esos personajes de la picaresca y de Cervantes los referentes al amor desempeñan un papel principal. Los
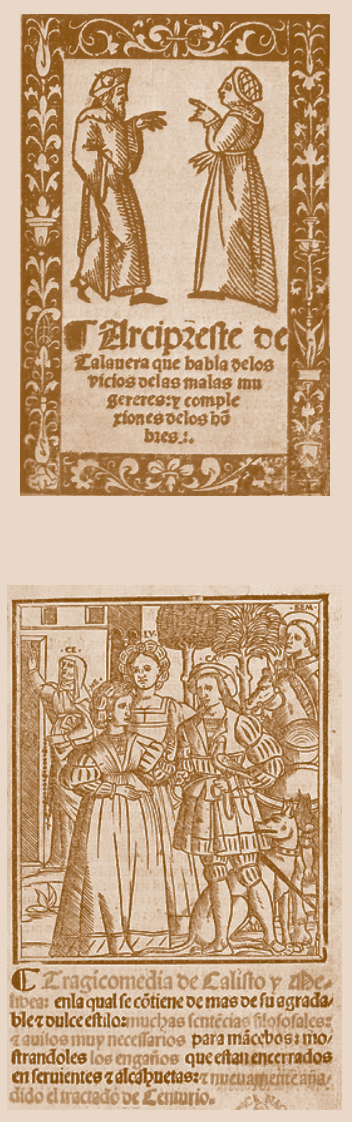
conflictos amorosos se extienden desde riñas de burdel hasta luchas entre aristócratas impregnados de la retórica del amor cortés. La violencia erótica, la fricción amorosa, refleja el cambio social a medida que costumbres establecidas y leyes pierden su vigencia con el desarrollo del nuevo Estado español. Personajes de diversas clases sociales se conocen, chocan, se vuelven a encontrar y con frecuencia se casan. El matrimonio como cierre narrativo aparece mucho porque es el contrato $-\mathrm{y}$ el sacramento- que resuelve conflictos y encauza el deseo hacia la reproducción y la estabilidad. Toda la agitación social, con sus consecuencias o expresión legal, aparece en Cervantes en la forma de conflictos eróticos y la inevitable aparición de agentes del orden. Hasta el asunto del matrimonio de la hija de Sancho cae bajo esta rúbrica o tendencia, como la de tantas parejas que van, a veces por caminos sinuosos, rumbo al altar. El sistema legal en proceso de evolución facilita soluciones a estas disputas no concebibles antes. Las nuevas leyes están por encima del severo código del honor y su promoción de la venganza privada, aún con las atrocidades que, desde nuestra perspectiva, la ley permitía. Todo este movimiento y evolución puede verse como encaminado hacia la sociedad burguesa de la que la novela será parte.

El desarrollo de la imprenta a fines del siglo XV, y especialmente durante el siglo XVI, y la centralización del sistema jurídico en España tuvieron consecuencias a primera vista contradictorias. La primera, atrapar al individuo en una red de restricciones: se encuentra ahora más estrechamente subordinado al Estado y sujeto a sus mecanismos penales. Está registrado, inscrito. Pero al mismo tiempo la ley impresa y por lo tanto más ampliamente diseminada y aplicada, propicia la democratización y la nivelación de las clases sociales. Las leyes del nuevo Estado mermaron el poder arbitrario de los aristócratas, que son ahora no sólo súbditos de la corona sino que están sujetos también a su renovado y robustecido aparato judicial. Los relatos de conflictos amorosos en el Quijote reflejan la movilidad social o el proceso de reajuste social producto de las nuevas leyes. Los conflictos amorosos abarcan todo el registro en Cervantes, pero los más significativos son los que reflejan roces entre clases sociales. Personajes de diferentes niveles se conocen, se enamoran, rompen voluntariamente o forzados a hacerlo por las circunstancias, se encuentran de nuevo y se casan. Lo ilegal, la transgresión, la corrupción transforman el sistema desde sus márgenes, re-escribiendo la ley, a veces con sangre, como en el episodio de las bodas de Camacho en la segunda parte del Quijote.

El repertorio escrito de la ley, el archivo, se hace cada vez más importante para la literatura porque es el más amplio registro del comercio entre 
humanos -es una forma primaria, básica de inscribir la variedad de la vida social, el registro del comportamiento anterior a las posibles generalizaciones y formulaciones sobre éste. Representa la cruda contingencia de lo real reducida a la escritura y la letra impresa. Por todo ello es un valioso depósito y reserva para la emergente novela, un tesoro de las muchas variantes de la buena y mala conducta humana. Los alienados de la sociedad -delincuentes, criminales, pecadores, locos- serán tipos igualmente codiciados por novelistas y representantes de la ley.

La literatura se convierte en archivo de lo prohibido, contrapeso del nutrido acervo de escritos doctrinales, que ha sido generalmente el contexto usado para interpretar a Cervantes por su fácil y numerosa accesibilidad. Lo prohibido tiende por su propia naturaleza a ser escaso en sus manifestaciones públicas y deja una tenue huella documental, excepto en expedientes criminales. Hay abundante información sobre la ley, sobre la supresión y castigo del crimen y el pecado, pero exigua documentación textual y contextual sobre los deleites y del deseo y las posibilidades de su satisfacción. Aquí es donde se equivocan Marcel Bataillon (1964), Alexander A. Parker (1975) y Alban Forcione (1984), estudiosos cuya obra sinceramente admiro y de quienes he aprendido no poco. Pero en su trabajo tergiversan el texto literario al hacer depender sus aproximaciones exclusivamente del abrumadoramente abundante contexto de la literatura devota y restrictiva. Para mí, la literatura es, en este sentido, su mismo mejor contexto al exponer las tentaciones del deseo en sus muchas manifestaciones; también el trabajo del historiador Stuart Schwartz (1997) sobre el archivo de la Inquisición, donde la evidencia escrita de las ofensas es más numerosa -sobre todo porque la Inquisición castigaba no tanto los actos pecaminosos como las expresiones aprobatorias o exculpatorias sobre éstos.

No me interesa dar una vez más con el Cervantes ortodoxo al que se le erigen estatuas y dedican discursos patrios -pienso en el monumento en la Plaza de España en Madrid. Busco al que escribe indagando sobre lo prohibido, regodeándose en él, no porque esté aliado a alguna ideología o pertenezca a una comunidad resentida como la de los conversos (detesto el Cervantes de Américo Castro), sino porque ha descubierto que esa es la literatura que aspira a alcanzar la verdad en el sentido más profundo. Estoy en completo acuerdo con Jean Canavaggio cuando escribe, en su excelente biografía del autor del Quijote, que "son las actitudes desviacionistas, por no decir perversas, las que retienen la mayoría de las veces la atención de Cervantes" (1992: 146). ¿Por qué será que tanto en el Quijote como en todas sus obras importantes indagará Cervantes sobre las perversidades del

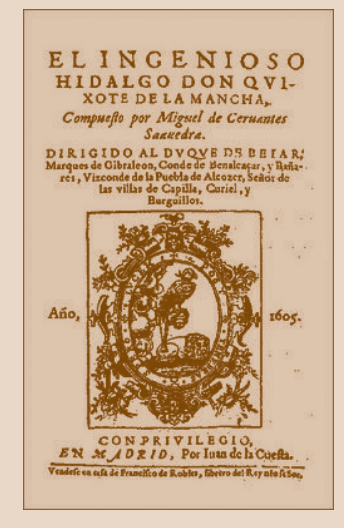


amor, y qué tiene todo esto que ver con la novela y con la literatura en general? ¿En qué estriba el placer de descubrir verdades tan desagradables de la condición humana? Pienso que la literatura nos da la oportunidad de gozar indirectamente y con poco riesgo los placeres de lo prohibido, cuyo atractivo se ejerce sobre todos nosotros. O tal vez porque, siguiendo a Georges Bataille (1961), lo vedado le confiere a lo prohibido un valor propio del que se nutre la literatura. Irónicamente es aquí donde el dulce y el utile de Horacio se dan cita, sólo que lo dulce es la dulzura de lo vedado y lo útil la contemplación y autocontemplación de la condición humana -de lo humano, lo terriblemente humano.

Mi propósito ha sido tomar en consideración el funcionamiento real del sistema jurídico en la época de Cervantes, no sólo en términos abstractos o generales sino del derecho tal y como fue formulado y aplicado en la España de la segunda mitad del siglo XVI y principios del XVII. En el terreno jurídico la literatura encuentra un sentido de lo concreto, de lo real y vigente que entra en conflicto con la narrativa y convencionalismos estilísticos derivados del tronco de la tradición narrativa europea. Los individuos ahora están sujetos a un estado que no conciben en términos ancestrales o personales -relaciones con iguales, subordinados o superiores- sino como un complicado conjunto de leyes que median entre ellos y la fuente del poder. El heroísmo en el sentido épico se ve ahora seriamente comprometido por las limitaciones impuestas al individuo por la ley. Esto afecta no sólo el concepto de sí mismo que se tenía sino también el de la colectividad. La obra de Cervantes constituye el primer testimonio literario sostenido de este cambio. Muestra una sociedad cada vez más litigiosa como resultado de la erosión de los privilegios de los nobles que va camino a las revoluciones del siglo XVIII, a la Ilustración, y eventualmente a la sociedad burguesa. Es lo anterior -además de su genio personal- lo que hace a Cervantes diferente de Dante, Boccaccio, y remontando la tradición, Virgilio y Homero.

En las historias de amor cervantinas se comete un crimen punible: hay un autor o culpable y una víctima, y un delito cuya gravedad se determina según la ley. El crimen se define con referencia a la legislación vigente y el culpable castigado de acuerdo a sus estipulaciones. Los argumentos son afectados por el derecho porque lo que los pone en movimiento es el crimen cometido -como en el caso de Fernando y Dorotea- y los castigos e indemnizaciones varían según lo dispuesto por los códigos. En suma, el derecho incide en la narrativa de Cervantes de las siguientes maneras: 1) estilo; lo concreto, los particulares y la terminología legal; 2) los argumentos basados en la secuencia crimen -castigo- indemnización o perdón; 3 ) 
la incorporación de subgéneros derivados del discurso legal (confesiones, relaciones, declaraciones); 4) un creciente número de relatos que giran en torno al matrimonio, que es el nivel más tangible y textual en el que se intersectan en Cervantes y la novelística subsiguiente el amor y el derecho; 5) la proliferación de jueces, alguaciles, cuadrilleros de la Santa Hermandad y letrados en sus novelas y relatos; 6) la inclusión de o referencia a documentos legales en la ficción, y que la ficción asuma la forma de uno de éstos - la relación en el caso de la picaresca.

Aunque no pocos han querido ver en Cervantes a un jurista, Ivo Domínguez (1972), con más mesura, le atribuye su familiaridad con el derecho a sus experiencias personales. Esas experiencias -la mayoría tropezones de diversa índole con la ley- hacen de Cervantes un súbdito representativo del renovado sistema político de su tiempo -los "documentos cervantinos" dan fe de ello. Lo que lo distingue a él, pienso, fue su trabajo de colector de impuestos para financiar la llamada "Armada Invencible." Realizar semejante tarea, de por sí plagada de escollos legales y conflictos potenciales de toda índole, lo llevó a la cárcel y a ser excomulgado. En sus labores Cervantes formaba parte de la burocracia patrimonial y sus complicados mecanismos jurídicos y protocolos de registro. Estas fueron las actividades que sumieron a Cervantes en el derecho tal y como estaba instituido y era practicado en la España de su época; experiencia práctica en el proceso mediante el cual el nuevo Estado ponía a los ciudadanos al servicio de su política. Se familiarizó íntimamente con el funcionamiento del sistema judicial y la burocracia penal en cuestiones referentes al derecho hereditario y a la constitución de patrimonios. Su propio perfil legal y penal, aunque borroso, se dibuja en esos "documentos cervantinos" que dan fe de su paso por la historia de su país y época.

Grisóstomo y Marcela, Dorotea y Fernando, Luscinda y Cardenio son todos personajes del Quijote cogidos en complicados aprietos amorosos que conducen al matrimonio. Las dificultades son, en algunos casos, jurídicas, y reflejan disparidades sociales y económicas similares a las que aparecen en conocidas comedias del Siglo de Oro como Fuenteovejuna, El alcalde de Zalamea, y El burlador de Sevilla. La intervención de Don Quijote en el embrollo provocado por Fernando, Dorotea, Luscinda y Cardenio da origen a un final típico de comedia, con múltiples promesas de matrimonio que restauran el orden. En la novela hay después casos más graves en que se ven involucrados el cautivo y Zoraida y, en la segunda parte, hay otros como aquel donde aparece la hija del morisco Ricote. En estos relatos, las complicaciones siguen siendo jurídicas, pero los conflictos no son sólo de 


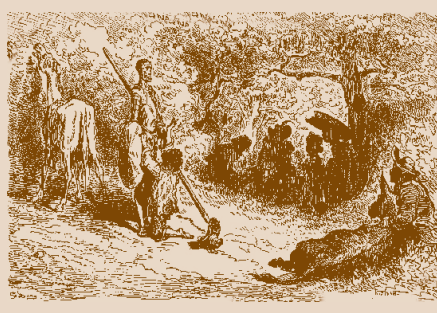

índole social y económica sino racial y religiosa. En todos, sin embargo, es la presencia de la ley lo que confiere a estas historias un matiz moderno, un tinte histórico contingente: no terminan con asesinatos múltiples, como en Shakespeare, subidas al cielo o descensos al infierno, como en Tirso. Los castigos y recompensas son más mundanales, y siempre incluyen el matrimonio como última solución, que remata el argumento. Los conflictos no son sólo provocados por transgresiones a la moral o a la doctrina religiosa, sino por violaciones -o posibles violaciones- de la ley, y deben resolverse en esa esfera, así como en la amorosa. El tono legalista del Quijote se establece relativamente pronto - primera parte, capítulo 22- cuando el hidalgo y su escudero liberan a doce galeotes. El episodio también contrapone el amor y la ley de forma aparentemente jocosa.

El capítulo de los galeotes ha sido objeto de mucho comentario, sobre todo la figura de Ginés de Pasamonte, ese novelista picaresco dentro de la ficción que reaparece en la segunda parte como el titiritero Maese Pedro. Mucho se ha hablado también de la disparidad existente entre el sentido de la justicia de don Quijote y el de los representantes de la ley que custodian a los galeotes. Pero el episodio posee una dimensión inexplorada y un personaje menor que (si se me perdona) ha escapado a la atención.

Se trata del incidente cuando don Quijote y Sancho se topan con doce galeotes, a quienes sus guardias conducen hacia la costa, para ser embarcados en las galeras donde padecerán trabajo forzado como remeros por períodos que varían según la sentencia de cada uno. El caballero está vivamente interesado en la causa del encarcelamiento de estos desventurados, y ve una oportunidad para ejercer su deber caballeresco de tomar armas contra abusos e injusticias. Haciendo caso omiso del consejo de los guardias, pero con el resignado consentimiento de éstos, don Quijote comienza a interrogar a los prisioneros sobre sus delitos y castigos. Es como una escena de tribunal en la que el caballero desempeña el papel de juez. También muchas piezas teatrales hacen uso de este recurso, entre ellas el entremés El juez de los divorcios, del propio Cervantes. La escena recuerda también varios episodios del Infierno de Dante, donde el peregrino interroga a los condenados sobre la naturaleza de sus pecados, para entender las penas que les han sido impuestas. Don Quijote "oye" unos seis casos, determina que los hombres han sido castigados injusta o excesivamente, y obliga a los guardias a liberarlos con la renuente asistencia de Sancho. Una vez liberados, les exige a los galeotes que se encaminen derecho a El Toboso, donde se deben arrojar a los pies de la bella Dulcinea, a quien narrarán su hazaña. Los antiguos prisioneros, como es lógico, rehúsan hacerlo, ofre- 
ciendo diversas razones, siendo una de las principales que, como prófugos de la justicia, deben dispersarse y huir "solos y divididos, y cada uno por su parte, procurando meterse en las entrañas de la tierra, por no ser hallados de la Santa Hermandad, que sin duda alguna ha de salir en nuestra busca" (p. 246). Enfurecido, don Quijote les suelta una sarta de insultos y ellos responden con una lluvia de piedras que deja aporreados y humillados al caballero, su escudero y sus cabalgaduras.

Se ha mencionado la ingratitud de los galeotes y el alto sentido del perdón de don Quijote. El episodio ha suscitado todo tipo de comentarios éticos, el contraste entre la justicia divina y la terrenal, y el aristocrático y obsoleto concepto de la justicia de don Quijote, en contraste con el nuevo sistema judicial que, a partir de los Reyes Católicos, ha pasado gradualmente a convertirse en la ley del Reino. Richard Kagan, gran especialista en el derecho español durante el Siglo de Oro, escribe:

Es precisamente la preponderancia de ese tipo de justicia -la del Estado- lo que da a la más importante novela de Miguel de Cervantes, Don Quijote, un giro tan irónico. Para la época en que Cervantes escribió sobre un patético hidalgo que sale a defender la justicia valiéndose de su valor caballeresco y audaces proezas, la mayoría de sus lectores habrían identificado la justicia con el mundo de abogados, jueces y otros "hombres de la ley". En este mundo legalista, la figura de Don Quijote no es tanto una broma como un anacronismo. Representaba una era mítica en que la justicia era posible sin la asistencia de abogados y montones de expedientes jurídicos; pero en el laberinto de las cortes de Castilla no había cabida para un caballero andante ya entrado en años (1981: 127).

La proeza caballeresca de poner en libertad a los galeotes, como atinadamente observa Sancho con alarma, los convierte a ellos en prófugos de la justicia, junto con los antiguos prisioneros. Era el suyo un grave "caso de corte", pues habían cometido un delito contra la Corona al liberar a hombres condenados por los tribunales del Rey, a cuyos representantes habían forzado y lesionado en el proceso. El guardián que le explica a don Quijote quiénes son los prisioneros se refiere a ellos como "gente de su Majestad." Se trata de delitos graves, empeorados por el hecho de haber sido cometidos en despoblado, a campo traviesa, lejos de las ciudades y del control de la ley. Cuando se internan en la Sierra Morena, para que don Quijote pueda hacer penitencia por Dulcinea, el caballero y Sancho también están huyendo de las autoridades, sobre todo de la Santa Hermandad. Prisionero del amor, don Quijote se interna en el monte para hacerse digno de Dulcinea siguiendo modelos caballerescos. Pero don Quijote, que ha liberado a delincuentes 
por medios violentos, es ahora un delincuente común. (Es el primer héroe de la tradición literaria occidental en ser prófugo de la justicia). Desde entonces hasta el final de la primera parte será perseguido por las autoridades. Cuando al fin lo capturan, los cuadrilleros entregan al triste hidalgo al cura y al barbero, sabedores de que, dada su condición mental, nunca podrá ser condenado. Pero de todos modos lo enviarán a casa, confinado en una jaula, un auténtico prisionero del amor y la ley. Esta es la historia dentro de la cual se aloja la que me propongo analizar hoy.

Hay un galeote, como dije, al que no se le ha prestado atención, pero que a mi entender es de importancia primordial para comprender las fuerzas entrecruzadas del amor y el derecho en el Quijote. Creo que encarna $-y$, en cierto sentido, incluso "representa"- los límites del conflicto entre el amor y la ley en la obra, y constituye también un magnífico ejemplo de la asombrosa capacidad de Cervantes para crear personajes complejos con una pasmosa economía de medios. Los límites a los que llega este relato son aquéllos más allá de los cuales es imposible concebir o representar el amor y el derecho como fuerzas que generan formas reconocibles, que originan lo legible, lo narrable. El relato del prisionero es lo inenarrable, lo inexpresable y, de hecho, la suya constituye una historia virtual de la que apenas tenemos un atisbo fugaz en el Quijote. Es una historia sobre la historia que no puede contarse, por así decirlo.

El galeote en cuestión es un tipo de Don Juan, un seductor en serie atrapado y sentenciado no por la ley divina, como el de Tirso de Molina, sino por las leyes del Reino. Es el único personaje en el Quijote juzgado y condenado por un delito de amor. Por eso lo llamo el "prisionero del sexo," pero también porque -con la venia póstuma de Norman Mailer que publicó un libro con ese título- parece haber sido esclavo de la pasión sexual, un compulsivo adicto al sexo. En un momento dado sostiene relaciones con cuatro mujeres al mismo tiempo. He aquí la escena:

Pasó adelante don Quijote y preguntó a otro su delito, el cual respondió con no menos, sino con mucha más gallardía que el pasado:

-Yo voy aquí porque me burlé demasiadamente con dos primas hermanas mías y con otras dos hermanas que no lo eran mías; finalmente, tanto me burlé con todas, que resultó de la burla crecer la parentela tan intrincadamente, que no hay diablo que la declare. Probóseme todo, faltó favor, no tuve dineros, vime a pique de perder los tragaderos, sentenciáronme a galeras por seis años, consentí: castigo es de mi culpa; mozo soy, dure la vida, que con ella todo se alcanza. Si vuestra merced, señor caballero, lleva alguna cosa con que socorrer a estos pobretes, Dios de lo pagará en el cielo y nosotros tendremos en la tierra cuidado de rogar 
a Dios en nuestras oraciones por la vida y salud de vuestra merced, que sea tan larga y tan buena como su presencia merece. Éste iba en hábito de estudiante, y dijo una de las guardas que era muy grande hablador $y$ muy gentil latino (pp. 240-241).

La escena sigue de cerca cambios ocurridos en el derecho penal español en la segunda mitad del siglo XVI. Felipe II, en 1552 en nombre de su padre, y en 1566 en el suyo propio como rey, conmutó para los ladrones el castigo de azote por una temporada en galeras. El cambio no se debió al aumento del delito de robo, sino a la necesidad de proveer de galeotes a la marina, en vísperas de la Armada Invencible de 1588. Francisco Tomás y Valiente escribe en su exhaustivo El derecho penal de la monarquía absoluta: "Como hacían falta brazos para el remo, todos estos pobretes, toda esta 'chusma' [...] fueron considerados sin más carne de galera [...] sin más requisito que cometer algún hurto y tener más de veinte años, o, a partir de 1566, más de diecisiete" (1969: 252). Sentenciar a un delincuente a galeras también lo sustraía de fueros regionales y lo hacía siervo exclusivo de la Corona, otra medida en el sentido de la unificación jurídica de la Península. El castigo por otros delitos, además del de robo -como violación e incesto, el caso de nuestro prisionero-, podía también ser de cuatro, y más tarde seis años, como galeote, en lugar de azotes o del patíbulo. La nobleza estaba exenta del castigo físico -llamado corporis aflictiva-, que era por naturaleza público, a fin de no manchar aún más su reputación. De modo que nuestro prisionero del sexo es un plebeyo de más de diecisiete años que ha salvado la vida debido a que la necesidad de remeros para la marina ha conducido a la conmutación de su sentencia por seis años en las galeras.

Permítaseme refugiarme momentáneamente en la relativa seguridad de la filología. Hay en este texto cinco palabras que merecen comentario: "burlar", "declarar", "parentela," "estudiante" y "demasiadamente." Las tres últimas parecen indicar que este galeote no es sólo un estudiante, sino más concretamente un estudiante de derecho. Obsérvese que es él quien hace el alegato en nombre de sus compañeros, y proclama que su castigo se adecúa al delito ("consentí"), como si fuera entendido en leyes y fuera competente para hacerlo. Toma, además, distancia de sus compañeros al referirse a ellos como "estos pobretes". Interpreto "declarar" como término jurídico, primero con el sentido de "deponer". El Diccionario de autoridades (1963/172639) explica: "DECLARAR. Vale también en lo forense, deponer, testificar, decir bajo juramento el reo, testigo o perito en causa criminal o pleito civil". En el Tesoro de la lengua castellana o española, de Sebastián de Covarrubias (1987/1611), descubrimos que en el siglo XVII también significaba "acla- 
rar", que es el significado general de la palabra en este caso: "DECLARAR. Manifestar lo que de suyo estaba oculto, oscuro y no entendido". La palabra conserva hoy ambos significados, pero favorece el jurídico. En la primera edición del Quijote no hay "diablo" capaz de entender la genealogía engendrada por el prisionero, pero en otras posteriores Cervantes lo cambió por "sumista". Esto inclina el caso en la dirección de una posible disputa sobre derechos hereditarios que, por supuesto, se rigen por las leyes del derecho testamentario en vez de caer bajo la jurisdicción de las penales.

Covarrubias define con precisión "parentela" como "los parientes de un linaje", que también tiene una resonancia legalista. La genealogía que se deriva de las relaciones sexuales del prisionero está tan enmarañada que no hay quién la desenrede: hermanos que son primos unos de otros, sobrinos que son también hijos, y sobrinas que son también hijas. Lo que indica el prisionero es que nadie, ni siquiera él con su superior dominio del idioma y pericia jurídica, sería capaz de redactar un documento en que se estableciese la legitimidad y se fijara un legado, un patrimonio -quién heredaría qué de quién- en forma clara y jurídicamente obligatoria. Esta confusión genealógica sería el peor delito del prisionero, según él insinúa al usar un término jurídico que significa la incapacidad de "declarar" correctamente, es decir de traducir al discurso jurídico sus actos con sus consecuencias. (Esto es lo más sugestivo de este episodio en términos literarios). La alusión a la enmarañada progenie puede por lo tanto también ser una forma sutil de defensa, pues si la causa en cuestión fueran la herencia y los patrimonios, sus fechorías constituirían un caso civil, no criminal, como ya se dijo. (Desde luego, también dijo que no tiene ningún dinero, así que la cuestión carece de consecuencias). Podemos observar que el texto y el subtexto de lo que dice el galeote revelan su formación jurídica.

Existen también pruebas históricas que indican que "estudiante" significa aquí estudiante de derecho. Este joven era buen latinista y buen retórico: hablaba bien, lo que lo predispone a la profesión jurídica. Pero también la mayoría de los estudiantes de su tiempo estudiaban leyes, independientemente de lo que acabaran haciendo después. Los estudiantes de derecho eran conocidos por su tendencia al escándalo individual y en grupo. Algunos aparecen en otras obras de Cervantes. De modo que también me inclino a creer que el prisionero es un estudiante de derecho debido a su comportamiento licencioso. Obsérvese su insolencia y la ligereza con que se refiere a sus acciones y, sobre todo, que es él quien ataca a don Quijote cuanto el caballero es derribado por las piedras que sus compañeros le lanzan: "y apenas hubo caído [don Quijote], cuando fue sobre él el estudiante 
y le quitó la bacía de la cabeza, y dióle con ella tres o cuatro golpes en las espaldas y otros tantos en la tierra, con que la hizo pedazos" (p. 247). Ésta es la última aparición del lascivo abogado en ciernes en el Quijote, puesto que se pierde en los bosques y montes, o en las "entrañas de la tierra", para escapar del orden público.

Parte de mis sospechas sobre el estudiante galeote procederían también de la siguiente palabra que quiero comentar -"burlar"-, porque los estudiantes de derecho eran dados a "burlas" o bromas. Eran bromistas notorios, como ya dije. Pero a causa de la pieza de Tirso de Molina, El burlador de Sevilla, "burlar" es el vocablo más importante de los cuatro que gloso. "Burlar" es una palabra común a las tres lenguas romances de la Península, aunque de origen desconocido, según Corominas (1997). Pero "burlar" no puede sino traer a la mente El burlador de Sevilla. Nuestro prisionero del sexo es sin dudas un "burlador." Pero según lo que el prisionero dice, y en especial el tono en que lo dice, lo sería en el sentido de seductor libertino. En la reciente edición del Quijote del Instituto Cervantes, coordinada por Francisco Rico (1998), una nota explica que en la jerga de pícaros y rufianes llamada "germanía", el verbo "burlar" significaba tener comercio sexual con alguien. Pudiera muy bien ser así, pero la palabra, incluso en este contexto especializado, debe haber conservado parte de su significado ordinario (engañar); de no ser así, dudo que Tirso la hubiera usado en su título. (¿Puede alguien imaginar que Fray Tirso titulara su obra algo así como El fornicador de Sevilla?). "Burlar a alguien" significa embaucar o engañar a alguien, que es la acepción con que se utiliza en la comedia de Tirso de Molina, donde significa seducir a una mujer usando artimañas, como lo hace Don Juan -haciéndose pasar por otros hombres, o haciendo promesas falsas de matrimonio-. Se trata de una forma de estupro, o violación, y era condenada por el derecho español con diversos grados de severidad. Pero obsérvese que el prisionero ha evitado la forma transitiva del verbo. No dice "burlado a", engañado a alguien, sino "burlado con". Ha convertido sus acciones en sexo consensual con dos hermanas que eran primas hermanas suyas y con otras dos que no lo eran, insinuando la complicidad de éstas en un menage à trois, o en este caso, menage à cinq. Si sometemos la ficción al sentido común, tendríamos que concluir que habría sido difícil mantener ocultas las aventuras con las diversas mujeres. El prisionero parece estar diciendo que disfrutaba de un par de felices triángulos amorosos, hasta que el intrincado linaje de los hijos que resultaron de ellos se interpuso. Esto lo aparta de Don Juan, que prefería las conquistas fugaces de una noche y no engendraba hijos.

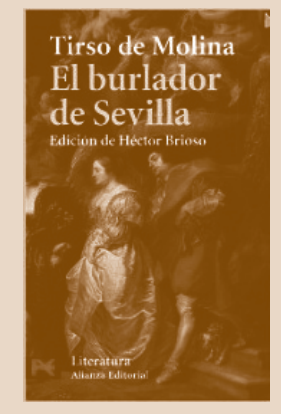


Pero no debe pasar inadvertida la sutileza de la caracterización de su delito por parte de este abogaducho incipiente. No es que burlara con sus primas hermanas, sino que lo había hecho "demasiadamente". Nótese el adverbio que emplea para calificar sus acciones: "demasiadamente", de latín de magis, "de más", "demasiado", "en exceso". Salvo que la forma normal en español, entonces y ahora, es "demasiado", aunque el Diccionario de la Real Academia de la Lengua (1956) recoge "demasiadamente", uso poco usual para dar énfasis al adverbio. De modo que no es la fechoría en sí, sino su repetición imprudente, excesiva, la que le trajo problemas al prisionero. Insinúa que de haberse divertido menos, o en forma un poco más discreta, con sus primas y las otras mujeres, no habría encontrado dificultades. No se menciona, desde luego, el incesto, porque, como caso de fornicación simple, la ley favorecía al prisionero. Sostener relaciones sexuales, aun con cuatro mujeres, no era un delito grave en sí, suponiendo, como se nos hace suponer, que eran solteras, al igual que el prisionero, y que estaban dispuestas a ello. Esto es lo que en la terminología jurídica del período -en la que se reconoce su molde escolástico- recibió el nombre de "fornicación simple" o fornicatio simplex, en contraste con la "fornicación calificada" (Schwartz, 1997). La simple era la relación sexual entre personas no casadas de sexos opuestos; la gravedad de la "fornicación calificada" aumentaba si una o ambas partes eran casadas, menores de edad, o si ambas eran del mismo sexo. De modo que el prisionero afirma haber cometido fornicación simple consensual con cuatro mujeres, de la cual surgieron descendientes cuyos lazos familiares resultaban difíciles de establecer. La única indicación de que el incesto pudiera haber sido un factor agravante se insinúa en la consanguinidad de los hijos, pero el prisionero la trata con ligereza, como hace con todo lo demás.

De modo que tenemos a un posible estudiante de derecho que ha dejado encinta varias veces a dos primas hermanas y a otras dos hermanas, y engendrado una complicada progenie. Acepta su castigo como acorde con su delito y declara que es joven y tendrá vida después de las galeras, frase que recuerda el estribillo de Don Juan siempre que le advierten de las futuras consecuencias de sus acciones: “Cuán largo me lo fiáis". Pero, mientras Don Juan se refiere a la muerte y la condena eterna, el prisionero habla de la vida terrenal y del castigo por las instituciones penales competentes. Siente optimismo hacia el futuro, o al menos alardea de desenfado y valor, rasgo común entre los reclusos de entonces -y tal vez de hoy también. Hay frivolidad en su tono, una pose de despreocupación que, otra vez, podría ser parte de una defensa o una manera de desviar la atención del aspecto más grave 
de su delito que sería, desde luego, el incesto. Detrás del velo de jocosidad, como tenía por costumbre, Cervantes ha deslizado el aspecto más serio y punible del personaje y sus acciones.

No nos dejemos engañar por este elocuente embaucador, dotado de tanta retórica y encanto: el prisionero había sido declarado culpable y sentenciado por estupro, o seducción alcanzada por un abuso de confianza, e incesto, incluso si creemos su historia de relaciones consensuales. La seducción de mujeres por la fuerza o medios menos violentos, en especial de vírgenes, viudas y monjas, era sancionada con severidad por el derecho español desde las Siete partidas en el siglo XIII. Esta misma recopilación de leyes -en vigor todavía en el siglo XVI como fuente supletoria- define el incesto como

un pecado que llaman en latín incestus, que quier tanto decir como pecado que ome faze yaciendo a sabienda con su pariente, o con parienta de su muger o de otra con quien ouiese yacido, fasta el quarto grado, o si yoguiesse alguno con su madrastra, o con madre o fija, o con su cuñada o con su nuera, o si alguno yoguiesse con muger de Orden o con su afijada o con su comadre (Cuarta Partida, Título II, ley 13, p. 27).

Me parece que la ley es clara, sobre todo tomando en cuenta el establecimiento del "quarto grado" de consanguinidad como incesto. Técnicamente, el incesto significaba sostener relaciones sexuales con un pariente con el que sería ilegal casarse, lo que se extendía a los primos, aunque existía la posibilidad de obtener dispensa de la Iglesia. A pesar de su elaborado floreo retórico, no hay dudas de que, como él mismo admite, el prisionero es culpable y el castigo es conforme al delito. Y el más grave que ha cometido es el incesto, no sólo por haber procreado un confuso clan endogámico -aunque esto es, sin duda, lo que procura evitar la prohibición. El incesto se contaba entre los delitos que seguían considerándose también pecados en los códigos españoles de entonces, a pesar de la gradual separación de éstos de la teología y del derecho canónico: se le llama "pecado" en el texto de las Siete partidas que acabo de citar.

El galeote, como hemos podido observar, hace honor a la descripción del guardia; se expresa con gallardía y demuestra ser un gran hablador. Se comporta muy dueño de sí mismo, y se dirige a don Quijote con insolencia, aunque las diferencias de clase resultan claras, pues lo llama "Señor caballero," aunque dada la facha del hidalgo el tono podría ser irónico. Tomando en cuenta sus antecedentes como seductor de varias mujeres, debe ser también apuesto, atractivo. Es impenitente, desenfadado y tiene confianza en su 
futuro. Hay algo en el galeote de narcisista, a juzgar por su comportamiento y el que lleve hábito de estudiante, para hacer alarde de su superioridad sobre sus compañeros, e incluso sobre los guardias. Es un fanfarrón. Creo que su narcisismo constituye una clave de su lado oscuro y de lo que él significa en la economía del amor y el derecho en el Quijote. Es aquí donde el incesto revela dimensiones imprevistas. Comporta el incesto un elemento narcisista, en el sentido de que entraña un deseo por otro que es, en parte, uno mismo; el yo que desea procura perpetuarse con un mínimo de diferencia. El otro deseado es una imagen del propio ser, como lo serán los resultados, los hijos. Hay también en el incesto una nota de autoconocimiento perverso, si damos a "conocimiento" un amplio sentido bíblico. Es como remontar el árbol genealógico para encontrar los orígenes propios y fundirse con ellos. Hay aspectos verdaderamente retorcidos en las aberraciones del prisionero; si seguimos especulando, en sus primas podría haber visto imágenes de su propia madre, para ser freudianos. Llevado a sus últimas consecuencias, no hay continuidad en su relato, no tiene conclusión porque el narcisismo es un colapso del ser dentro de sí mismo, lo que sugiere el mito clásico al hacer que Narciso se ahogue en su propia imagen. Es una circunvolución narrativa que conduce a su propia borradura. Volvemos a la imposibilidad de "declarar," a la imposibilidad de su relato.

El prisionero lleva al extremo la relación entre el amor y la ley al violar el tabú fundamental que constituye la base misma de la vida en sociedad: la prohibición del incesto, que conduce al intercambio de parejas sexuales y a la mezcla de personas de distintos clanes o grupos. Sin ésta, se desintegraría el proceso de reproducción dentro de un orden social y el ser humano regresaría al caos de la naturaleza. Sin este no inicial, sin esa primera ley, la civilización dejaría de existir. Ésa es la tragedia de Edipo, como sabemos. En el pasaje que he estado analizando, el caos está representado por esa genealogía enredada que escapa al control de la ley, que no puede reducirse al discurso jurídico para entrar en el comercio social y político del Estado. Tras haber sido educado en sus estudios para hacer la ley inteligible, legible en un sentido lato, el prisionero se ha burlado de ella actuando de manera que la hace resistente a la escritura y la lectura. El hecho de que cuando lo veamos por primera vez esté encadenado demuestra que los custodios de la sociedad son conscientes del peligro que este individuo representa. Los guardias llevan consigo los documentos en que está inscrita la historia del prisionero, donde se le ha atrapado en la red del discurso legal; la sentencia en que aparecen asentados su delito y su castigo: "Aunque llevamos aquí el registro y la fe de las sentencias de cada uno destos malaventurados, no es 
tiempo éste de detenerles a sacarlas ni a leellas" (pp. 236-237). Es esta una historia que nunca llegamos a leer, pero a la que el prisionero ha dado su sello de aprobación, para luego ofrecer su propia versión de los hechos. Es una historia ilegible debido a que, en su horror, excede los límites de lo representable y, como el narcisismo, es una narración que se pliega sobre sí misma, por lo que permanece en la bolsa del guardia -suponemos que el documento irá enrollado o doblado.

La brevísima actuación del prisionero del sexo esconde una de las historias inenarrables; una sexualidad desenfrenada que viola insistentemente la más elemental de las leyes, la prohibición del incesto. Por eso, más allá de las leyes que lo condenan, el prisionero es sentenciado a un mundo exclusivamente masculino -las galeras- en el que, de dar rienda suelta a su deseo, la única salida para éste sería el homosexualismo, la peor de las fornicaciones calificadas. Esta posibilidad está también inscripta en el narcisismo del prisionero y le confiere también a su historia un viso de circunvolución porque se cierra sobre sí misma. Por ello no tiene de final; el prisionero desaparece de la novela, a su historia le falta cierre. Al repudiar toda ley el prisionero excluye la posibilidad de la inteligibilidad, se niega a figurar en el archivo, a ser inscripto, registrado en éste. Por eso también se jacta de que tendrá vida después de las galeras; para él no existe el tiempo o la finalidad y final de la teleología. A Cervantes le fascinaban los límites de la literatura, los puntos más problemáticos de su arte, que se han convertido en pasto de las teorías críticas de la actualidad, que él no sólo anticipa sino rebasa.

Además de demostrar lo incrustado que está el Quijote en la realidad jurídica de su tiempo, y de poner de manifiesto mediante esta "historia inenarrable" el fondo oscuro y perverso del amor, el prisionero del sexo revela, como reflejo lateral, una faceta importante de don Quijote. El hidalgo también aspira a una libertad absoluta, irrestricta, salvo por los convencionalismos del amor cortés que subliman su deseo por Aldonza Lorenzo. Don Quijote es un prisionero del amor correlativo del prisionero del sexo. Esa es la razón profunda, me parece a mí, por la que Don Quijote pone en libertad al prisionero, y tal vez también aquélla por la que éste aporrea al hidalgo una vez que lo derriban de Rocinante. Es una paliza a su doble, a su hermano, a su pariente, paralela a la violencia sexual a la que somete a sus primas.

El análisis de las transacciones amorosas contra el fondo del nuevo derecho español le ofreció a Cervantes la oportunidad de dar nuevas inflexiones a viejas historias, e incluso le reveló algunas historias totalmente nuevas. El archivo, acaparador, autoritario, se erigió en un compendio de narraciones alternativas en competencia con la tradición literaria, en un canon vincu- 
lado por el discurso legal al nuevo Estado. Algunas de las historias nuevas logran, incluso, escapar del archivo para formar una constelación de relatos imposibles, que Cervantes no podía aún narrar. Son también historias ejemplares, pero que a causa de su naturaleza virtual anunciaban una literatura aún por llegar.

\section{REFERENCIAS}

Auerbach, E. (1950) [original alemán, 1946]. Mimesis: la representación de la realidad en la literatura occidental. México: Fondo de Cultura Económica.

Bataille, G. (1961). Les larmes d'Eros. París: Pauvert.

Bataillon, M. (1964). "Cervantes y el matrimonio cristiano". En Varia lección de clásicos españoles. Madrid: Gredos, pp. 238-255.

Canavaggio, J. (1992) [1986]. Cervantes: en busca del perfil perdido. $2^{\mathrm{a}}$ ed. Madrid: Espasa Calpe.

Cervantes, M. de (1998) [1605, 1615]. Don Quijote de la Mancha. Ed. Francisco Rico. Barcelona: Instituto Cervantes.

Corominas, J. (1997). Diccionario crítico etimológico castellano e hispánico. 6 vols. Cuarta reimpresión. Madrid: Gredos.

Covarrubias, S. de (1987) [1611]. Tesoro de la lengua castellana o española. Ed. Martín de Riquer. Barcelona: Editorial Alta Fulla.

Diccionario de autoridades (1963) [1726-39]. Madrid: Gredos.

Diccionario de la lengua española (1956). Madrid: Real Academia EspanolaEspasa Calpe.

Domínguez, I. (1972). El derecho como recurso literario en las novelas ejemplares de Cervantes. Montevideo: Publicaciones Lingüísticas y Literarias del Instituto de Estudios Superiores de Montevideo.

Forcione, A. K. (1984). Cervantes and the Mystery of Lawlessness: A Study of "El casamiento engañoso" and "El coloquio de los perros". Princeton, NJ: Princeton University Press.

Grimm, J. (1991) [1882]. "Von der Poesie im Recht”. Kleinere Schriften 6. Hildesheim, NY: Olms-Weidmann, pp. 152-191.

Kagan, R. (1981). Lawsuits and Litigants in Castile: 1500-1700. Chapel Hill, NC: University of North Carolina Press.

Parker, A. A. (1967). Literature and the Delinquent: The Picaresque Novel in Spain and Europe, 1599-1753. Edimburgo: Edinburgh University Press.

(1975). The Philosophy of Love in Spanish Literature: 1480-1680. Edimburgo: Edinburgh University Press.

Saldaña, Q. (1926). "La criminología de El Quijote (notas para su estudio)". Revue hispanique, № 68, pp. 552-581.

Schwartz, S. (1997). "Pecar en las colonias: Mentalidades populares, Inquisición y actitudes hacia la fornicación simple en España, Portugal y las colo- 
nias americanas". Cuadernos de Historia Moderna, No 18, Madrid: Universidad Complutense, pp. 51-67.

Smith, C. (1983). The Making of the "Poema de mío Cid". Cambridge: Cambridge University Press.

Tomás y Valiente, F. (1969). El derecho penal de la monarquía absoluta (siglos XVI-XVII-XVIII). Madrid: Tecnos. 